\title{
Fabrication and Properties of Hybrid Membranes Based on Poly (Vinyl Alcohol), Sulfosuccinic Acid and Salts of Heteropolyacid with or without Silica for Fuel Cells Applications
}

\author{
Said Maarouf ${ }^{1, *}$, Zouhair Alouane ${ }^{1,2}$, Bouchra Tazi ${ }^{2}$, Farhate Guenoun $^{1}$, Khalil Fouad ${ }^{3}$ \\ ${ }^{1}$ Laboratoire de Chimie Biologie Appliquée à l'Environnement, Faculté des Sciences, Université Moulay. Ismail, Zitoune Meknès, B.P. \\ 11201, Maroc \\ ${ }^{2}$ Laboratoire de Chimie, DSB, Ecole Nationale d'Agriculture. km. 10, Route Haj Kaddour,.B.P. S/40, Meknès, 50001, Maroc \\ ${ }^{3}$ Laboratoire de Chimie Appliquée (LCA). Faculté des Sciences et Technique,-Route d'Imouzzer Fès, B.P. 2202, Maroc
}

\begin{tabular}{l} 
A R T I C L E I N F O \\
\hline Article history: \\
Received: 24 June, 2020 \\
Accepted: 21 September, 2020 \\
Online: 20 October, 2020 \\
\hline Keywords: \\
Fuel cells \\
Polymer electrolyte membranes \\
Poly (vinylalcohol) \\
Silicotungstic acid \\
Sulfosuccinic acid \\
\hline
\end{tabular}

\begin{abstract}
A B S T R A C T
Novel ionic polymers were synthesized by crosslinking of poly (vinylalcohol) (PVA) with sulfosuccinic acid (SSA) and silicotungstic acid (SiWA) with or without silica. The polymer electrolyte membrane fuel cell (PEMFC) was developed using solution casting method. Infrared (IR) spectra revealed that the Keggin structure was insered in the PVA films. The thermal decomposition of the PVA/SSA/SiWA/SiO 2 membranes showed good thermal stability up to $200^{\circ} \mathrm{C}$. Water uptake ranged between $31 \%$ and $88 \%$. The maximum conductivity has been found to be $6,72.10^{-3} \mathrm{~S} . \mathrm{cm}^{-1}$ at room temperature for PVA/SSA/SiWA containing $10 \%$ of silica weight. The ion exchange capacity of this membrane was 1,75 mmol. $\mathrm{g}^{-1}$. The results showed that these membranes presented very promising performances for use in Proton Exchange Membrane Fuel Cells.
\end{abstract}

\section{Introduction}

Exhaustion of non-renewable fossil fuel invokes the development of environmentally friendly alternative energy sources. Fuel cells are being considered as interesting alternatives power sources for a wide range of applications, ranging from portable devices to electric vehicles $[1,2]$. Fuel cells are of great interest in the recent research due to their attractive properties. They offer many advantages, such as environmentally benign, high energy efficiency and lower emission of pollutants [3, 4]. The principal component in PEMFCs is the proton exchange membrane (PEM) which is used as proton (or charge carriers) provider from anode to cathode. The membrane must be proton conductor with mechanical strength and chemical stability. The perfluorosulfonated membrane, Nafion produced by Dupont is the most used as a polymer in PEMFCs because of its combined chemical, electrochemical, and mechanical stabilities with high proton conductivity $\left(\sim 0.1 \mathrm{~S} . \mathrm{cm}^{-1}\right)$ at ambient temperature [5].

However, it possesses some drawbacks, and especially its high cost; presents a high water swelling characteristic which reduces the lifespan of the membrane and decrease in conductivity at

*Corresponding Author: Said Maarouf, Email: saidmaarouf576@gmail.com elevated temperature [6]. So, the utilization of Nafion membrane in fuel cell is limited. Therefore, "Hydrocarbon" proton conducting membranes have been designed as an alternative to perfluorinated membranes $[7,8]$. High performance polyarylenes are resistant to oxidation, thermo-stable and are mechanically strong with a relatively high glass transition temperature ( $\mathrm{Tg})$, sulfonated poly (ether ether) ketone [9], sulfonated polyimide [10], polybenzimidazole [11], sulfonated polyposphazene [12] and sulfonated poly(vinylalcohol) (PVA) [1,13], have been synthesized.

However, to enhance the proton conductivity of the polymers, a high acid content is needed. Unfortunately, this can decrease the mechanical strength of the composite membranes, or, even worse, degrade it, especially at higher temperatures [14].

Among the materials investigated, Poly (vinylalcohol) (PVA) has attracted great attention due to its good mechanical properties, chemical stability, low cost, film forming ability, and high hydrophilic behavior $[15,16]$. The PVA membranes are poor proton conductors and dissolve in water. Hence, to impart protonic conductivity as well as mechanical stability to PVA membranes, a crosslinking agent containing sulfonic acid group 
can be used, such as concentrated sulfuric acid, sulfosuccinic acid (SSA), acid sulfophthalic [13,17].

Many researchers have studied the properties of cross-linked PVA/SSA membranes as a function of SSA content. Recently, C.González, and A. Greus studied the proton-conducting membrane based on PVA/SSA/GO. Their experimental results showed the proton conductivity of the order of $2,06.10^{-3} \mathrm{~S}^{\mathrm{cm}} \mathrm{cm}^{-1}$ for the PVA/SSA humidified membrane [18]. Furthermore, Kim and al. demonstrated that the PVA/SSA/silica hybrid membranes prepared via a sol-gel process presents excellent proton conductivity [1].

In general, heteropolyacids (HPAs), and $\mathrm{SiO}_{2}$ have served as an essential inorganic proton conductor for organic-inorganic hybrid membranes [19-22]. HPAs, a class of superionic conductor in their fully hydrated condition and thus it provides high proton conducting pathway [23,24]. For example, hydrated silicotungstic acid ( $\mathrm{H} 4 \mathrm{SiW} 12 \mathrm{O} 40 \cdot 28 \mathrm{H} 2 \mathrm{O})$ has an ionic conductivity of $2.10^{-2} \mathrm{S.cm}^{-1}$ at room temperature [25-27]. However, HPAs are generally water-soluble. Consequently, a major research objective is to fix the HPAs in stable structure by forming composites which can maintain or increase the proton conductivities of the membranes [22,28,29].

In our previous studies [30,31], we have synthesized the HPA and $\mathrm{SiO}_{2}$ based hybrid membranes (PVA/PVP/SSA/HPAs/ $/ \mathrm{SiO}_{2}$ ). These membranes showed that proton conductivity increase significantly with the HPAs content. Silica was also added in the membranes preparation solution in order to improve thermal and mechanical stabilities of the PVA/PWA membranes.

The aim of this study was to prepare membranes for possible PEMFC. To do this, PVA/SiWA/SiO ${ }_{2}$ hybrid membranes containing sulfonic acid groups were synthesized using solution casting method. Sulfonic acid groups were introduced into the PVA matrix by modifications of the chemical structure of the PVA through esterification with sulfosuccinic acid (SSA), which has sulfonic acid groups. In addition heteropolyacid and silica particles in the polymer matrix at varying concentrations, which were expected to achieve high proton conductivity, thermal stability and high water uptake. The effect of membrane thicknesses has also been studied. Ion exchange capacities have been studied for PVA/SSA/10wt.\% $/ \mathrm{SiWA} / \mathrm{SiO}_{2}$ membranes. The prepared composite polymer electrolyte membranes have been characterized by various techniques TGA, and FTIR.

\section{Experimental}

\subsection{Materials}

Poly(vinylalcohol) with a molecular weight of 70.000 g.mol ${ }^{-1}$ was received from Sigma Aldrich. Sulfosuccinic acid 70wt.\% from sigma Aldrich, Silicotungstic acid from Panreac, Silica $60 \mathrm{~A}^{\circ}$, from sigma Aldrich.

\subsection{Membrane preparation}

$10 \mathrm{wt} \%$ PVA solution was prepared by dissolving the preweighed amount of PVA in deionized water at $80^{\circ} \mathrm{C}$ for at least 4 $\mathrm{h}$. The solution of PVA was mixed with SSA in mass ratio of $0,10 \mathrm{~g}$ at $80^{\circ} \mathrm{C}$ for 3 hours. Then, Silicotungtic acid $(0 \%-40 \%)$ was added to the above solution and stirred for 2 hours at $80^{\circ} \mathrm{C}$ to produce PVA/SSA/SiWA membrane. Silica $(1 \%-15 \%)$ was subsequently added to the above solution and stirred at $70^{\circ} \mathrm{C}$ for about 4 hours to produce $\mathrm{PVA} / \mathrm{SSA} / \mathrm{SiWA} / \mathrm{SiO}_{2}$ membrane. The solvent was removed by evaporation at room temperature for 16 $\mathrm{h}$, then the cast membranes were allowed to dry at $60^{\circ} \mathrm{C}$ for $24 \mathrm{~h}$. and then in the oven at $140^{\circ} \mathrm{C}$ for 1 hour. Membranes thicknesses in the dray state are about 50 to $650 \mu \mathrm{m}$.

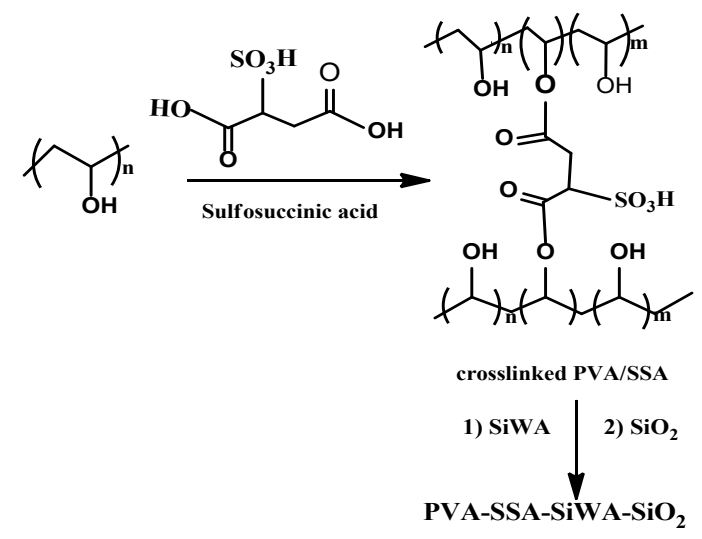

Figure 1: Molecular structure of PVA/SSA polymer matrix and silicotungstic acid with silica.

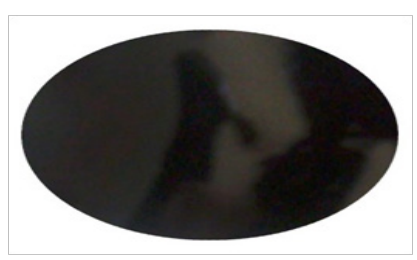

Figure 2: Homogeneous, transparent thin film of PVA-SSA-SiWA-SiO

\subsection{Water Uptake}

Membrane samples were dried at $60{ }^{\circ} \mathrm{C}$ for $24 \mathrm{~h}$ and weighed after (Wdry). Then immersed in boiling water during $24 \mathrm{~h}$. The membranes were then removed, and the samples were finally weighed (Wwet). The water uptake of the membrane is deduced using the following equation:

$$
W U=\frac{W w e t-W d r y}{W d r y} * 100
$$

\subsection{Proton conductivity}

Resistances were measured using a cell coupled with potentiostat-galvanostat-Amel instrument (70-50), the measurement cell is show in Figure 3 and has been described elsewhere (Table.1). It composed of two identical compartments linked with two platinum electrodes with the same surface as the membrane. In addition, in each compartment, Luggin capillaries are connected to two saturated calomel electrodes. The membrane is placed between the two compartments during measurements. The ionic conductivity of the membranes was determined by polarization. In $1 \mathrm{M} \mathrm{NaCl}$ solution, the potential drop between the two references electrodes was measured, following application of a constant direct current $(0.5-5 \mathrm{~mA})$. The proton conductivity $(\sigma)$ was obtained using the following equation:

$$
\sigma=\frac{\mathrm{e}}{\mathrm{RS}}
$$

where $\sigma$ is the ionic conductivity in S.cm ${ }^{-1}, \mathrm{R}$ is the Resistance of the membrane in $\Omega$, e is the thickness of the membrane in $\mathrm{cm}$, and $\mathrm{S}$ is the membrane surface in $\mathrm{cm}^{2}$. 


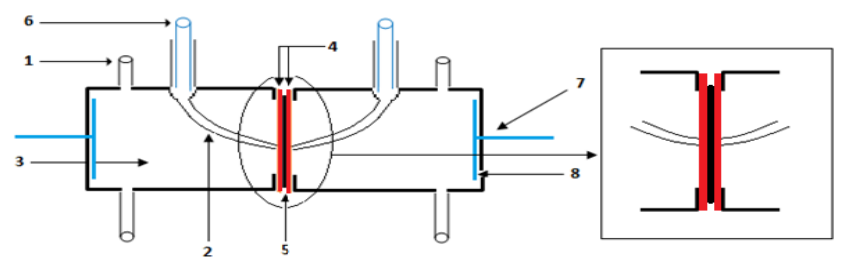

Figure 3: measurement cell of proton conductivity.

Table 1: Description of measurement cell of proton conductivity

\begin{tabular}{l|l} 
1: Capillary (allow entry & 5: Membrane. \\
and exit of the solutions). & 6: Reference electrodes. \\
2: Capillary Luggin. & 7: Stem platinum. \\
3: Electrolyte. & 8: Platinum electrodes. \\
4: Teflon gaskets. & \\
\hline
\end{tabular}

\subsection{FTIR spectroscopy}

The spectrum of the membranes was recorded with a MVP 2 STAR ART DIAMANT $\left(600-4000 \mathrm{~cm}^{-1}\right.$, resolution $\left.4 \mathrm{~cm}^{-1}\right)$.

\subsection{Thermal gravimetric analysis (TGA)}

TGA was accomplished by thermogravimetric analyzer, TA 60 SHIMADZU TG-DTA. The samples were then heated from $25{ }^{\circ} \mathrm{C}$ to $600{ }^{\circ} \mathrm{C}$ at a heating rate of $20^{\circ} \mathrm{C} \cdot \mathrm{min}^{-1}$.

\subsection{Ion exchange capacity (IEC) and fixed ion concentration}

IEC has been determined by titration method. A sample membrane $(0,375 \mathrm{~g}$ to $0,765 \mathrm{~g})$ was immersed in a $250 \mathrm{ml}$ of $1 \mathrm{M}$ $\mathrm{HCl}$ solution and stirring for $1 \mathrm{~h}$ to change them into the $\mathrm{H}^{+}$form. The samples were then washed with deionized water to remove excess $\mathrm{HCl}$, and then equilibrated with $230 \mathrm{ml}$ of $\mathrm{NaCl}(0.1 \mathrm{M})+$ $20 \mathrm{ml}$ of $\mathrm{NaOH}(0.1 \mathrm{M})$ solution for $24 \mathrm{~h}$ at room temperature to permit the exchange between protons and sodium ions. Thereafter, $25 \mathrm{ml}$ of the solution was titrated with $\mathrm{HCl}(0.1 \mathrm{M})$ to evaluate the amount of $\mathrm{H}^{+}$generated from the exchange process. From the titration, the ion exchange capacity was determined from the following relation:

$$
I E C=\frac{n\left(H^{+}\right)}{\left(W_{d r y}\right)}
$$

where $n\left(\mathrm{H}^{+}\right)$is the number of moles of proton sites present in the membrane and Wdry is the weight of the dry membrane. Fixed ion concentration (FIC) can be determined from the following equation:

$$
F I C=\frac{I E C}{W U}
$$

where (WU) is the water uptake of the membrane sample.

\section{Results \& Discussions}

\subsection{Thermal gravimetric analysis (TGA)}

The thermal degradation behavior of PVA/SSA, $\mathrm{PVA} / \mathrm{SSA} / \mathrm{SiWA}$, and $\mathrm{PVA} / \mathrm{SSA} / \mathrm{SiWA} / \mathrm{SiO}_{2}$ composites membranes was illustrated in figure 4 . Three major stages of the thermal decomposition can be considered. The first stage of the decomposition, which occurs between 25 and $200{ }^{\circ} \mathrm{C}$, is the loss of absorbed water molecules formed after the esterification reaction of the membranes. Most of the absorbed water molecules in the membranes are supposed to exist in a bound state rather than in free molecules state. The water molecules seem to have been bound directly to the polymer chains and / or the $-\mathrm{SO}_{3} \mathrm{H}$ groups via hydrogen bonds [1]. The second decomposition stage between 200 and $400^{\circ} \mathrm{C}$, is the degradation of the sulfonic acid groups $\left(-\mathrm{SO}_{3} \mathrm{H}\right)$. The final major decomposition step comes about between 400 and $500{ }^{\circ} \mathrm{C}$, which is ascribed to decomposition of salt of silicotungstic acid combined with silica. It is seen from TGA curves, that the thermal stability of the hybrid membranes is improved probably due to the additive effect of $\mathrm{SiWA}$ and $\mathrm{SiO}_{2}$ fillers and the chemical cross-linked reaction between the PVA and SSA.

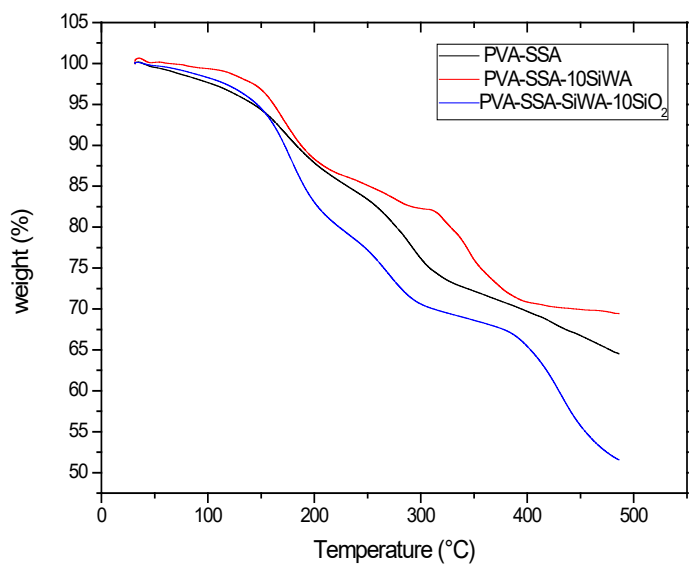

Figure 4: TGA curves for PVA/SSA, PVA/SSA/SiWA, and $\mathrm{PVA} / \mathrm{SSA} / \mathrm{SiWA} / \mathrm{SiO}_{2}$.

\subsection{Fourier transform infrared spectroscopy}

Figure 5 represents the F.T.I.R spectrum of the PVA/SSA, $\mathrm{PVA} / \mathrm{SSA} / \mathrm{SiWA}$ and $\mathrm{PVA} / \mathrm{SSA} / \mathrm{SiWA} / \mathrm{SiO}_{2}$ composite membranes. In the PVA/SSA/SiWA blend membranes, the characteristic ester absorption band (-COO) appeared around $1710 \mathrm{~cm}^{-1}[32]$, and the band at $1030 \mathrm{~cm}^{-1}$ is attributed to $\left(-\mathrm{SO}_{3} \mathrm{H}\right)$ group [32]. These spectral data confirm the esterification between $-\mathrm{OH}$ in PVA and $-\mathrm{COOH}$ in SSA [1]. The peaks at $3300 \mathrm{~cm}^{-1}$ (OH stretching), $2921 \mathrm{~cm}^{-1}$ (symmetric $\mathrm{CH}_{2}-$ ), and the band at $1420 \mathrm{~cm}^{-1}$ is for (-CH3) bending which are characteristic of PVA. The peaks at $969.03 ; 914.16 ; 789.04$ and $1141.89 \mathrm{~cm}^{-1}$ which are respectively attributed to the $\mathrm{W}=\mathrm{Od}, \mathrm{W}-\mathrm{Ob}-\mathrm{W}$ and $\mathrm{W}-$ $\mathrm{Oc}-\mathrm{W}$ and $\mathrm{O}-\mathrm{Si}-\mathrm{O}$. The presence of these peaks in the spectra F.T.I.R confirms that silicotungstic acid is inserted into the blend membranes PVA/SSA/SiWA, the characteristic bands (Si-O-Si) appeared around 1082.14 and $1219.31 \mathrm{~cm}^{-1}$ were observed in the spectra of the PVA/SSA/SiWA/ $\mathrm{SiO}_{2}$ hybrid membrane. This demonstrates that the esterification reaction was complete between the Poly (vinylalcohol) chains and the sulfosuccinic acid.

\subsection{Water uptake and proton conductivity of the membrane PVA/SSA/SiWA}

Figure 6 shows the water uptake and proton conductivity of the membranes PVA/SSA/xwt.\%SiWA as function of the silicotungtic acid content. The water uptake varies from $47 \%$ to 
$60 \%$. As shown in Figure 6, The water uptake increases with the increase of silicotungstic acid, and the maximum is obtained for $10 \mathrm{wt} . \%$ of SiWA. After that, the addition of silicotungstic acid leads to a decrease in water uptake of the membrane. Invese behavior can be explained by the chemical structure of the PVA/SSA network. An increase in water uptake at low SiWA content maybe is due the restricted degree of their swelling as also of the hydrophilicity of silicotungstic acid to due presence of keggin cage in PVA/SSA/HPA bridged-matrix [33,34].

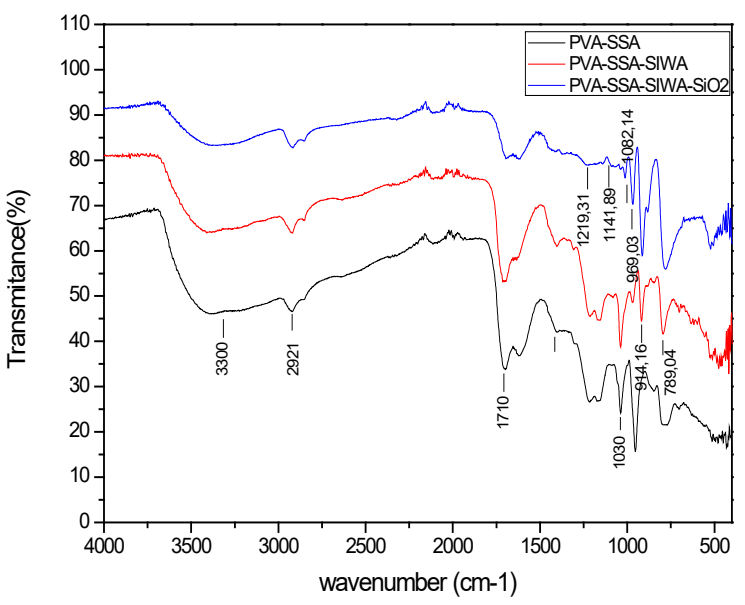

Figure 5: F.T.I.R spectra of PVA/SSA, PVA/SSA/SiWA, and $\mathrm{PVA} / \mathrm{SSA} / \mathrm{SiWA} / \mathrm{SiO}_{2}$ hybrid membranes.

The proton conductivity has been determined, as shown in this figure; the ionic conductivity of $\mathrm{PVA} / \mathrm{SSA} / \mathrm{xwt} \% \mathrm{SiWA}$ membranes varies from $1,100.10^{-3} \mathrm{~S}^{\mathrm{cm}} \mathrm{cm}^{-1}$ to $3,015.10^{-3} \mathrm{~S}_{\mathrm{cm}} \mathrm{cm}^{-1}$. The higher value is obtained for the composition PVA/SSA/10wt.\%SiWA, which is much higher than that of the pure PVA films and pure 12-tungstogermanic heteropolyacid [35]. The results indicated that PVA film, composited with sulfosuccinic acid and silicoptungstic acid is a new kind of excellent high proton conductor.

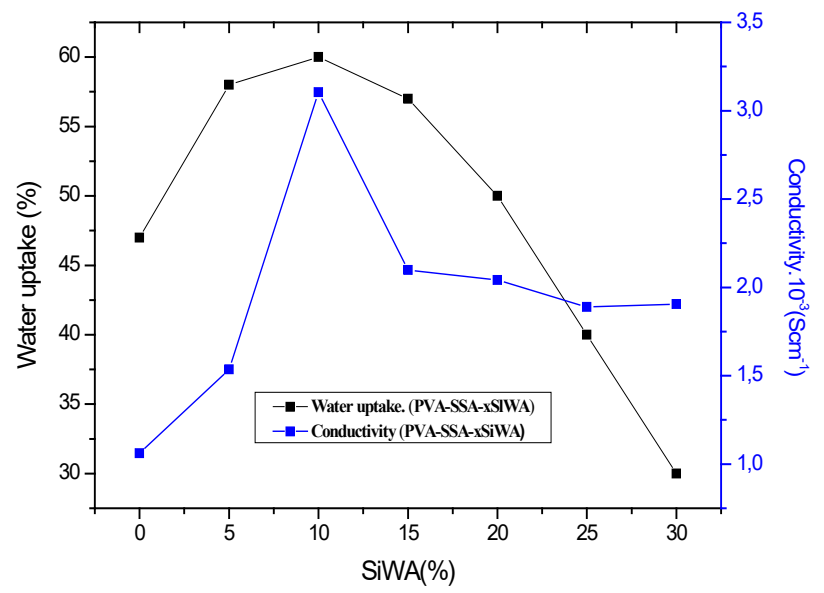

Figure 6: water uptake and proton conductivity of the hybrid membranes PVA/SSA/xwt.\%SiWA with different amounts of SiWA.

Figure 7 shows a plot of water uptake of the membranes PVA/SSA $/ 10 \mathrm{wt} . \%$ SiWA as a function of the membrane thickness.
The water absorption increases with the thickness of the membrane in the range $100-600 \mu \mathrm{m}$. It therefore goes from $28 \%$ for the PVA/SSA/10wt.\%SiWA membrane of $110 \mu \mathrm{m}$ thickness to $64 \%$ for the PVA/SSA/10wt.\%SiWA membrane of $550 \mu \mathrm{m}$ thickness.

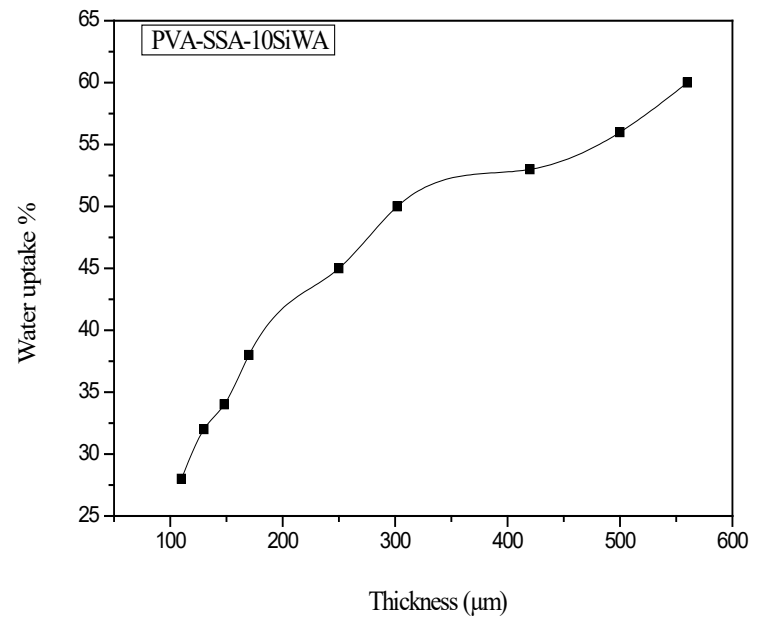

Figure 7: Water uptake of PVA/SSA/10wt.\%SiWA membrane with thicknesses.

Figure 8 represents the ionic conductivity of the membrane PVA/SSA/10wt.\%SiWA at saline media $(\mathrm{NaCl} 1 \mathrm{M})$ as a function of the membranes thickness at room temperature. Ionic conductivity values increase from $0,567.10^{-3}$ to $3,668.10^{-3} \mathrm{~S}_{\mathrm{cm}} \mathrm{cm}^{-1}$ In line with thickness values from 100 to $650 \mu \mathrm{m}$ thick. This agrees well with the published results of B. Tazi and al. [22].

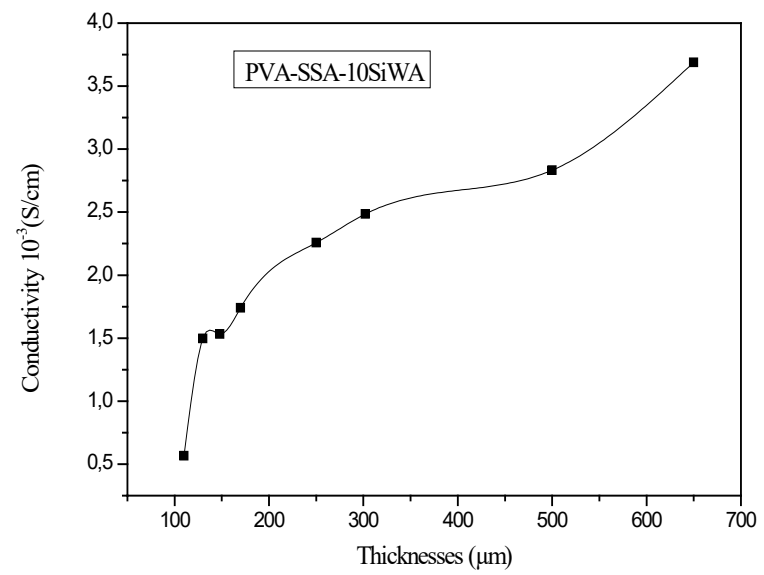

Figure 8: Proton Conductivity of PVA/SSA/10wt.\%SiWA membrane with thicknesses.

\subsection{Water uptake and proton conductivity of the membrane $\mathrm{PVA} / \mathrm{SSA} / 10 \mathrm{wt} . \% \mathrm{SiWA} / \mathrm{SiO}_{2}$}

The water uptake of the membranes PVA/SSA/SiWA/ywt. $\% \mathrm{SiO}_{2}$ as function of $\mathrm{SiO}_{2}$ content $(0 \mathrm{wt} . \% \leq$ $\mathrm{y} \leq 16 \mathrm{wt} . \%$ ) varies from $60 \%$ to $88 \%$. As shown in figure 9 . We notice that the water uptake varies with the silica percentage. Hence, the maximum which is equal to $88 \%$ was obtained for the 
membrane PVA/SSA/SiWA/10wt.\% $\mathrm{SiO}_{2}$. Thus, over $10 \mathrm{wt} \%$ of silica, the water uptake of this membrane starts decreasing.

This figure shows that the ionic conductivities of PVA/SSA/SiWA/ywt. $\% \mathrm{SiO}_{2}$ membranes increase with the increase weight of $\mathrm{SiO}_{2}$ percentage. The ionic conductivities go from $3,105 \cdot 10^{-3} \mathrm{~S}^{-\mathrm{cm}^{-1}}$ for the membrane without $\mathrm{SiO}_{2}$ to $6,720.10^{-3} \mathrm{~S}^{-\mathrm{cm}^{-1}}$ for the membrane containing $\mathrm{SiO}_{2}$ (Table 2). The proton conductivity of the membrane based on PVA/SSA/SiWA/10wt. $\% \mathrm{SiO}_{2}$ reaches a maximum of $6,72.10^{-3}$ S.cm ${ }^{-1}$, and decreases when the $\mathrm{SiO}_{2}$ content exceeds 10 wt. $\%$. The obtained value is higher than that of the Nafion ${ }^{\circledR} 112$ membrane $\left(5,9.10^{-3} \mathrm{~S}^{\left.-\mathrm{cm}^{-1}\right)}\right.$ [36]. This is in agreement with the results which show that the latter membrane also has the best hydration rate. These membranes then experience a decrease in proton conductivity when the $\mathrm{SiO}_{2}$ content exceeds $10 \%$. The inverse behaviors of the water uptake and ion exchange capacity (IEC) explain this behavior. As figure 12 shows. These results indicate that an inverse in water content can lead to higher proton conductivity at a low $\mathrm{SiO}_{2}$ content. However, large adsorption of water in membranes does not simply improve proton conductivity, but also dilutes the charges carries [5], which causes a decrease in proton conductivity at high $\mathrm{SiO}_{2}$ content in the membranes.

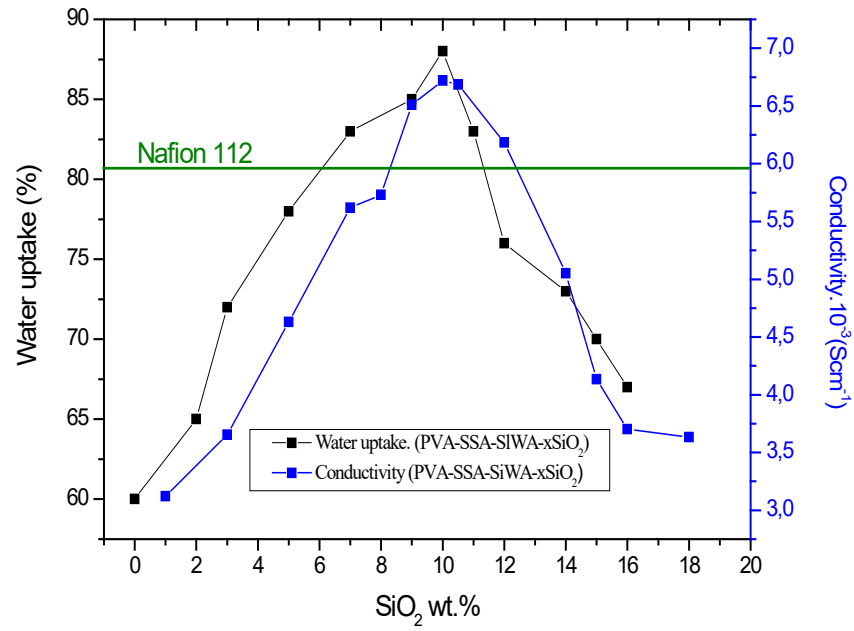

Figure 9: water uptake and proton conductivity of the membranes

PVA/SSA/SiWA/ywt. $\% \mathrm{SiO}_{2}$ with different amounts of $\mathrm{SiO}_{2}$

Table 2: Ionic conductivities $\left({\left.\mathrm{S} . \mathrm{cm}^{-1}\right)}^{-1}\right.$ for Nafion ${ }^{\circledR} 112$, PVA-SSA-10wt.\%SiWA and PVA-SSA-SiWA-10wt. $\% \mathrm{SiO}_{2}$ membranes

\begin{tabular}{|c|c|c|c|}
\hline Membranes & Nafion $^{\circledR} 112$ & $\begin{array}{c}\text { PVA/SSA/10wt. } \\
\% \mathrm{SiWA}\end{array}$ & $\begin{array}{c}\mathrm{PVA} / \mathrm{SSA} / \mathrm{SiWA} \\
/ 10 \mathrm{wt} . \% \mathrm{SiO}_{2}\end{array}$ \\
\hline $\begin{array}{c}\text { Ionic conductivity } \\
10^{-3}{\mathrm{~S} . \mathrm{cm}^{-1}}^{-1}\end{array}$ & 5,900 & 3,105 & 6,720 \\
\hline
\end{tabular}

Figure 10 shows the ionic conductivity of PVA/SSA/SiWA/10wt. $\% \mathrm{SiO}_{2}$ composite membrane as function thicknesses. The ionic conductivity of the composite membranes are in the order of $10^{-3} \mathrm{~S} . \mathrm{cm}^{-1}$. This figure shows that the ionic conductivity of the membrane increases when the membrane thickness increases. It goes from $0,672.10^{-3} \mathrm{~S}_{\mathrm{cm}} \mathrm{cm}^{-1}$ for the PVA/SSA/SiWA/10wt. $\% \mathrm{SiO}_{2}$ membrane $110 \mu \mathrm{m}$ thick to $6,72.10^{-3}{\mathrm{~S} . \mathrm{cm}^{-1}}^{-1}$ for PVA/SSA/SiWA/10wt. $\% \mathrm{SiO}_{2}$ membrane 450 $\mu \mathrm{m}$ thick, for thicknesses greater than $450 \mu \mathrm{m}$ the ionic conductivity remains close to $6,72.10^{-3} \mathrm{~S} . \mathrm{cm}^{-1}$.

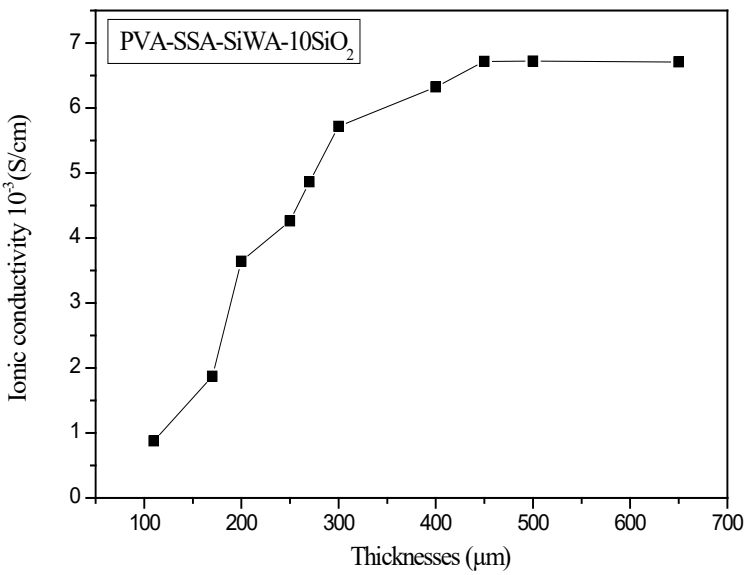

Figure 10: Proton Conductivity of PVA/SSA/SiWA/10wt. $\% \mathrm{SiO}_{2}$ membrane with thicknesses

\subsection{Ion exchange capacity and fixed ion concentration}

Figure 11(a,b) shows a plot of the ion exchange capacity (IEC) and fixed ion concentration as function of SiWA content. As shown in figure 11(a), the IEC of PVA/SSA/SiWA hybrid membrane varies from 0,90 to $2,20 \mathrm{mmol} . \mathrm{g}^{-1}$, and increases with SiWA content up to a maximum value of $2,20 \mathrm{mmol} . \mathrm{g}^{-1}$ obtained with PVA/SSA/35wt.\%SiWA hybrid membrane, the value obtained is higher than Nafion $115\left(0,90 \mathrm{mmol.g}^{-1}\right)$ [36]. This result indicates that an increase in silicotungstic acid content can lead to higher ion exchange capacity. At low HPA concentrations, the looser interaction between PVA and SiWA would provide less compact space for protons to be transported rather easily, resulting in higher ion exchange capacity. However, as the HPA concentration increased further, the interaction between PVA and SiWA would became stronger. The stronger interactions between not only PVA and SiWA but also PVA and SSA seem to inhibit the proton transport through the composite membranes, leading to lower ion exchange capacity.

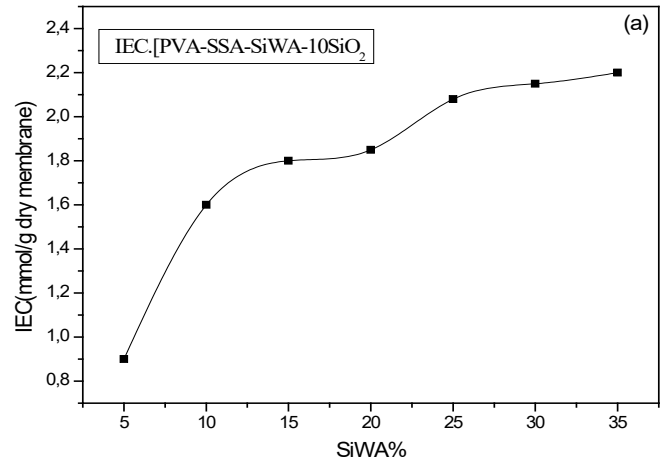

Figure 11(a): Effect of SiWA content on ion exchange capacity of PVA/SSA/SiWA membranes. 
As shown in figure 11(b), the fixed ion concentration (FIC) of the PVA/SSA/SiWA hybrid membrane. The (FIC) values were observed to increase greatly from 5 to $35 \mathrm{wt} . \%$ SiWA. The ion concentration sites increased with increasing the weight percent of silicotungstic acid. The ion concentration sites increased with the add of silicotungstic acid.

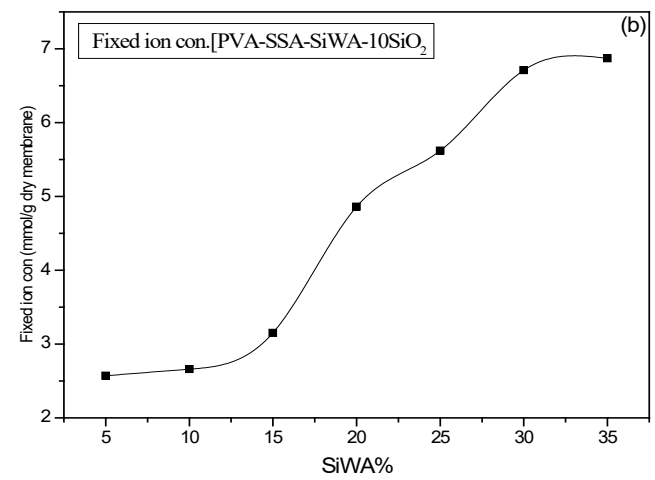

Figure 11(b): Effect of SiWA content on fixed ion concentration of PVA/SSA/SiWA membranes.

Figure 12 shows the IEC and water uptake of the membranes PVA/SSA/SiWA/ywt. $\% \mathrm{SiO}_{2}$ as function of $\mathrm{SiO}_{2}$ content. As shown in this plot, the measured IEC value of the PVA/SSA/SiWA/ywt.\% $\% \mathrm{SiO}_{2}$ hybrid membranes decreases as the silica content increases from 2 to $10 \%$.

in the other side, the water uptake of the $\mathrm{PVA} / \mathrm{SSA} / \mathrm{SiWA} / \mathrm{ywt} \% \mathrm{SiO}_{2}$ membranes increases with the increase of $\mathrm{SiO}_{2}$ content and reaches a maximum value of $88 \%$ for $10 \%$.wt $\mathrm{SiO}_{2}$ content membrane.

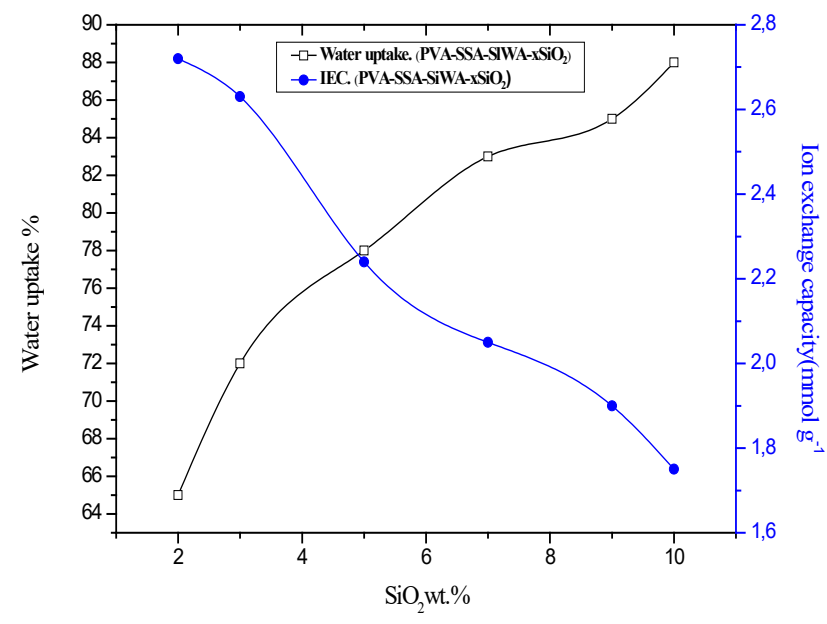

Figure 12: Water uptake and ion exchange capacity of the membranes based on PVA/SSA/10wt.\%SiWA/ywt. $\% \mathrm{SiO}_{2}$

\section{Conclusion}

In the present work, we synthesized a new proton-conducting polymer membrane based on PVA/SSA/SiWA/SiO 2 . The composite membranes were characterized by various techniques. The crosslinked networks and the formation of the intermolecular interactions between the hydroxyl groups on PVA and sulfosuccinic acid in membranes were proved with FTIR study. TGA showed that the membranes are thermally stable up to $200{ }^{\circ} \mathrm{C}$. Moreover, high proton conductivity was obtained at room temperature for the membranes $\mathrm{PVA} / \mathrm{SSA} / 10 \mathrm{wt} . \% \mathrm{SiWA}$ and PVA/SSA/SiWA/10wt. $\% \mathrm{SiO}_{2}$, are about $3,105.10^{-3}$ and $6,72.10^{-3}$ $\mathrm{S} . \mathrm{cm}^{-1}$ respectively. The obtained ion exchange capacities values decreases as the $\mathrm{SiO}_{2}$ content increases and reaches a maximum value of 1,75 mmol.g ${ }^{-1}$ for the membrane PVA/SSA/SiWA/10wt. $\% \mathrm{SiO}_{2}$. This value is higher than that of the standard values of Nafion ${ }^{\circledR} 112$ and Nafion ${ }^{\circledR} 115$ commercial membranes (use as reference membranes), which do not exceed 1 mmol. $\mathrm{g}^{-1}$. Therefore, it can be concluded that the new composite polymer electrolyte membrane PVA/SSA/SiWA/10wt. $\% \mathrm{SiO}_{2}$ shows potential applications in PEMFC.

\section{References}

[1] D.S. Kim, H.B. Park, J.W. Rhim, Y.M. Lee, "Preparation and characterization of crosslinked PVA/SiO2 hybrid membranes containing sulfonic acid groups for direct methanol fuel cell applications," Journal of Membrane $\quad$ Science, $\quad$ 240(1-2), 2004. https://doi.org/10.1016/j.memsci.2004.04.010

[2] J. Qiao, T. Okada, H. Ono, "High molecular weight PVA-modified PVA/PAMPS proton-conducting membranes with increased stability and their application in DMFCs," Solid State Ionics, 180(23-25), 1318-1323, 2009. https://doi.org/10.1016/j.ssi.2009.08.010

[3] M.M. Hasani-Sadrabadi, E. Dashtimoghadam, S.R. Ghaffarian, M.H.H Sadrabadi, M. Heidari, H. Moaddel, "Novel high-performance nanocomposite proton exchange membranes based on poly (ether sulfone)," Renewable $\quad$ Energy, $\quad 3(1), \quad 226-231, \quad 2010$ https://doi.org/10.1016/j.renene.2009.05.026

[4] C.-C. Yang, "Synthesis and characterization of the cross-linked PVA/TiO2 composite polymer membrane for alkaline DMFC," Journal of Membrane Science, $\quad \mathbf{2 8 8}(1-2), \quad$ 51-60, 2007. https://doi.org/10.1016/j.memsci.2006.10.048

[5] J. Qiao, T. Hamaya, T. Okada, "New highly proton-conducting membrane poly (vinylpyrrolidone)(PVP) modified poly (vinyl alcohol)/2-acrylamido2-methyl-1-propanesulfonic acid (PVA-PAMPS) for low temperature direct methanol fuel cells (DMFCs)," Polymer, 46(24), 10809-10816, 2005. https://doi.org/10.1016/j.polymer.2005.09.007

[6] M.-C. Clochard, T. Berthelot, C. Baudin, N. Betz, E. Balanzat, G. Gébel, A. Morin, "Ion track grafting: A way of producing low-cost and highly proton conductive membranes for fuel cell applications," Journal of Power Sources, 195(1), 223-231, 2010. https://doi.org/10.1016/j.jpowsour.2009.07.016

[7] C.H. Park, C.H. Lee, M.D. Guiver, Y.M. Lee, "Sulfonated hydrocarbon membranes for medium-temperature and low-humidity proton exchange membrane fuel cells (PEMFCs)," Progress in Polymer Science, 36(11), 1443-1498, 2011. https://doi.org/10.1016/j.progpolymsci.2011.06.001

[8] W. Vielstich, A. Lamm, H.A. Gasteiger, Handbook of fuel cells: fundamentals technology and applications, Wiley New York, 2003.

[9] L. Li, J. Zhang, Y. Wang, "Sulfonated poly (ether ether ketone) membranes for direct methanol fuel cell," Journal of Membrane Science, 226(1-2), 159167, 2003. https://doi.org/10.1016/j.memsci.2003.08.018

[10] J. Fang, X. Guo, S. Harada, T. Watari, K. Tanaka, H. Kita, K. Okamoto, "Novel sulfonated polyimides as polyelectrolytes for fuel cell application. 1. Synthesis, proton conductivity, and water stability of polyimides from 4,4 '-diaminodiphenyl ether-2, 2 '-disulfonic acid," Macromolecules, 35(24), 9022-9028, 2002. https://doi.org/10.1021/ma020005b

[11] J. Lobato, P. Canizares, M.A. Rodrigo, J.J. Linares, "PBI-based polymer electrolyte membranes fuel cells: temperature effects on cell performance and catalyst stability," Electrochimica Acta, 52(12), 3910-3920, 2007. https://doi.org/10.1016/j.electacta.2006.11.014

[12] Q. Guo, P.N. Pintauro, H. Tang, S. O'Connor, "Sulfonated and crosslinked polyphosphazene-based proton-exchange membranes," Journal of Membrane Science, 154(2), 175-181, 1999. https://doi.org/10.1016/S03767388(98)00282-8

[13] J.-W. Rhim, H.B. Park, C.-S. Lee, J.-H. Jun, D.S. Kim, Y.M. Lee, "Crosslinked poly (vinyl alcohol) membranes containing sulfonic acid group: proton and methanol transport through membranes," Journal of Membrane Science, 238(1-2), 143-151, 2004. 
[14] H. Chen, S. Wang, F. Liu, D. Wang, J. Li, T. Mao, G. Liu, X. Wang, J. Xu, Z. Wang, "Base-acid doped polybenzimidazole with high phosphoric acid retention for HT-PEMFC applications," Journal of Membrane Science, 596, 117722, 2020. https://doi.org/10.1016/j.memsci.2019.117722

[15] L. Lebrun, E. Da Silva, M. Metayer, "Elaboration of ion-exchange membranes with semi-interpenetrating polymer networks containing poly (vinyl alcohol) as polymer matrix," Journal of Applied Polymer Science, 84(8), 1572-1580, 2002. https://doi.org/10.1002/app.10420

[16] G. Hirankumar, S. Selvasekarapandian, M.S. Bhuvaneswari, R. Baskaran, M. Vijayakumar, "AC impedance studies on proton conducting polymer electrolyte complexes (PVA+ CH 3 COONH 4)," Ionics, 10(1-2), 135-138, 2004. DOI: $10.1007 / \mathrm{BF} 02410322$

[17] C. Chanthad, J. Wootthikanokkhan, "Effects of crosslinking time and amount of sulfophthalic acid on properties of the sulfonated poly (vinyl alcohol) membrane," Journal of Applied Polymer Science, 101(3), 19311936, 2006. https://doi.org/10.1002/app.23660

[18] C. González-Guisasola, A. Ribes-Greus, "Dielectric relaxations and conductivity of cross-linked PVA/SSA/GO composite membranes for fuel cells," Polymer Testing, 67, 55-67, 2018. https://doi.org/10.1016/j.polymertesting.2018.01.024

[19] P. Staiti, A.S. Arico, V. Baglio, F. Lufrano, E. Passalacqua, V. Antonucci, "Hybrid Nafion-silica membranes doped with heteropolyacids for application in direct methanol fuel cells," Solid State Ionics, 145(1-4), 101107, 2001. https://doi.org/10.1016/S0167-2738(01)00919-5

[20] S.P. Nunes, B. Ruffmann, E. Rikowski, S. Vetter, K. Richau, "Inorganic modification of proton conductive polymer membranes for direct methanol fuel cells," Journal of Membrane Science, 203(1-2), 215-225, 2002. https://doi.org/10.1016/S0376-7388(02)00009-1

[21] B. Ruffmann, H. Silva, B. Schulte, S.P. Nunes, "Organic/inorganic composite membranes for application in DMFC," Solid State Ionics, 162, 269-275, 2003. https://doi.org/10.1016/S0167-2738(03)00240-6

[22] B. Tazi, O. Savadogo, "Effect of Various Heteropolyacids (HPAs) on the Characteristics of Nafion ${ }^{\circledR}$-HPAS Membranes and their $\mathrm{H} \sim 2$ 2/O 2 Polymer Electrolyte Fuel Cell Parameters," Journal of New Materials for Electrochemical Systems, 4(3), 187-196, 2001.

[23] I. V Kozhevnikov, "Catalysis by heteropoly acids and multicomponent polyoxometalates in liquid-phase reactions," Chemical Reviews, 98(1), 171198, 1998. https://doi.org/10.1021/cr960400y

[24] M. Misono, "Heterogeneous catalysis by heteropoly compounds of molybdenum and tungsten," Catalysis Reviews Science and Engineering, 29(2-3), 269-321, 1987. https://doi.org/10.1080/01614948708078072

[25] O. Nakamura, I. Ogino, T. Kodama, "Temperature and humidity ranges of some hydrates of high-proton-conductive dodecamolybdophosphoric acid and dodecatungstophosphoric acid crystals under an atmosphere of hydrogen or either oxygen or air," Solid State Ionics, 3, 347-351, 1981. https://doi.org/10.1016/0167-2738(81)90111-9

[26] P. Staiti, "Proton conductive membranes constituted of silicotungstic acid anchored to silica-polybenzimidazole matrices," Journal of New Materials for Electrochemical Systems, 4(3), 181-186, 2001.

[27] O. Nakamura, T. Kodama, I. Ogino, Y. Miyake, "High-conductivity solid proton conductors: Dodecamolybdophosphoric acid and dodecatungstophosphoric acid crystals," Chemistry Letters, 8(1), 17-18, 1979. https://doi.org/10.1246/cl.1979.17

[28] C.W. Lin, Y.F. Huang, A.M. Kannan, "Cross-linked poly (vinyl alcohol) and poly (styrene sulfonic acid-co-maleic anhydride)-based semiinterpenetrating network as proton-conducting membranes for direct methanol fuel cells," Journal of Power Sources, 171(2), 340-347, 2007. https://doi.org/10.1016/j.jpowsour.2006.10.081

[29] S.M.J. Zaidi, S.D. Mikhailenko, G.P. Robertson, M.D. Guiver, S. Kaliaguine, "Proton conducting composite membranes from polyether ether ketone and heteropolyacids for fuel cell applications," Journal of Membrane Science, 173(1), 17-34, 2000. https://doi.org/10.1016/S0376-7388(00)00345-8

[30] S. Maarouf, B. Tazi, F. Guenoun, "Synthesis and characterization of new composite membranes based on polyvinylpyrrolidone, polyvinyl alcohol, sulfosuccinic acid, phosphomolybdic acid and silica," J Chem Pharmaceut Res, 8, 387-395, 2016.

[31] S. Maarouf, B. Tazi, F. Guenoun, "Preparation and Characterization of New Composite Membranes containing Polyvinylpyrrolidone, Polyvinyl alcohol, Sulfosuccinic acid, Silicotungstic acid and Silica for Direct Methanol Fuel Cell applications.”," J. Mater. Environ. Sci., 8, 2870-2876, 2017.

[32] J.E. Castanheiro, A.M. Ramos, I.M. Fonseca, J. Vital, "Esterification of acetic acid by isoamylic alcohol over catalytic membranes of poly (vinyl alcohol) containing sulfonic acid groups," Applied Catalysis A: General, 311, 17-23, 2006. https://doi.org/10.1016/j.apcata.2006.05.039

[33] F. Lufrano, G. Squadrito, A. Patti, E. Passalacqua, "Sulfonated polysulfone

www.astesj.com as promising membranes for polymer electrolyte fuel cells," Journal of Applied Polymer Science, 77(6), 1250-1256, 2000. https://doi.org/10.1002/1097-4628(20000808)77:6<1250::AID-

APP9>3.0.CO;2-R

[34] S. Hietala, M. Koel, E. Skou, M. Elomaa, F. Sundholm, "Thermal stability of styrene grafted and sulfonated proton conducting membranes based on poly (vinylidene fluoride)," Journal of Materials Chemistry, 8(5), 11271132, 1998. DOI: $10.1039 /$ A708288F

[35] Q. Wu, S. Tao, H. Lin, G. Meng, "Preparation, characterization and protonconductivity of silica gel containing $71 \mathrm{wt} . \% 12$-tungstogermanic heteropoly acid," Materials Chemistry and Physics, 64(1), 25-28, 2000 https://doi.org/10.1016/S0254-0584(99)00244-8

[36] S. Anisa, A. Utami, "Preparation of Sulfonated PVA-TMSP Membranes for Direct Methanol Fuel Cell," Makara Journal of Science, 95-100, 2013. https://doi/org/10.7454/mss.v16i2.1403 